\title{
Regional deindustrialization: concepts, causes, effects and the Brazilian case
}

\author{
Desindustrialização regional: conceitos, causas, efeitos e o caso \\ brasileiro
}

ISSN 0104-530X (Print) ISSN 1806-9649 (Online)

\author{
José Alderir Silva' ${ }^{1}$ (])
}

\begin{abstract}
How to cite: Silva, J. A. (2019). Regional deindustrialization: concepts, causes, effects and the Brazilian case.
\end{abstract} Gestão \& Produção, 26(4), e4682. https://doi.org/10.1590/0104-530X4682-19

\begin{abstract}
This paper aims to analyze the process of deindustrialization of the Brazilian economy from a regional perspective. Since the mid-2000s there has been an intense debate about the process of deindustrialization in the Brazilian economy, obtaining significant advances in the causes, consequences and, especially, the emphasis given to the role of industry in the development of Brazil. However, the deindustrialization in the Brazilian economy is treated in a homogeneous way, so that the discussion in the regional perspective is practically disregarded. This paper attempts to reduce this debate gap in the sense that it develops concepts appropriate to the regional space and explains its causes.
\end{abstract}

Keywords: Industry; Brazil; Regional economy.

Resumo: Este trabalho tem como objetivo analisar o processo de desindustrialização da economia brasileira na perspectiva regional. Desde meados dos anos 2000 tem ocorrido um intenso debate sobre o processo de desindustrialização na economia brasileira, obtendo significativos avanços no que diz respeito às causas, consequências e, principalmente sobre a ênfase dada ao papel da indústria no desenvolvimento do Brasil. Contudo, a desindustrialização na economia brasileira é tratada de forma homogênea, de modo que a discussão na perspectiva regional é praticamente desconsiderada. Este trabalho tenta reduzir um pouco essa lacuna do debate no sentido de que desenvolve conceitos adequados ao espaço regional e explana suas causas.

Palavras-chave: Indústria; Brasil; Economia regional.

\section{Introduction}

This paper aims to analyze the process of deindustrialization of the Brazilian economy from the regional perspective in the period 1995 to 2015 , seeking to identify in which region this process has been concentrated. Since the mid-2000s, there has been an intense debate about the process of deindustrialization in the Brazilian economy, obtaining significant advances regarding the causes, consequences and, especially, the emphasis given to the role of industry in the development of Brazil.

The so-called new-developmentalists defend the hypothesis that the Brazilian economy suffers from a process of deindustrialization derived from the Dutch disease, the latter caused by the real overvaluation of the exchange rate. According to Oreiro \& Feijó (2010) and Bresser-Pereira \& Marconi (2008), the deepening of the commercial and financial opening of the Brazilian economy, which began in the 1980s, combined with the commodity boom in the 2000s was the main responsible for this overvaluation.

On the other hand, part of orthodoxy, Barros \& Pereira (2008), argues that Brazil does not suffer from a process of deindustrialization, but goes through a process of modernization of the productive structure of the country propitiated by the cheapening of imported capital goods. Given this, the difficulty of some sectors would be a natural process of selecting activities that the country has comparative advantages and not a process of de-industrialization.

The other part of the orthodoxy, Bonelli \& Pessôa (2010) and Bonelli \& Pinheiro (2012), defends the thesis that the country was over-industrialized, that is, with a level of industrialization above that allowed by its productive factors. So deindustrialization in

\footnotetext{
${ }^{1}$ Departamento de Engenharias - DENGE, Universidade Federal Rural do Semi-arido - UFERSA, R. Gamaliel Martins, 587, Bairro Alto da Alegria, CEP 59515-000, Angicos, RN, Brasil, e-mail: jose.silva@ufersa.edu.br
}

Received Mar. 1, 2018 - Accepted May 2, 2018

Financial support: None. 
Brazil is nothing more than a return to the pattern determined by its productive factors.

However, the deindustrialization in the Brazilian economy within this debate is treated in a homogeneous way, as if all the regions were in the same circumstances, the discussion in the regional perspective being almost disregarded.

From a regional perspective, it is possible that one region has increased its share while another has declined. In other words, the first has followed a natural process of industrialization while the second region suffers from deindustrialization, so the policies adopted must be distinct for both regions. Therefore, this paper attempts to alleviate this gap in the debate around the Brazilian economy, drawing attention to the analysis of deindustrialization in the regional perspective. Moreover, the papers that attempt to analyze the deindustrialization process at the regional level do not find a definition of the adequate concept (See for example, Spíndola \& Lima (2015), using their appropriate definitions for national economies. Thus, the concept of deindustrialization used in this article will be defined in the next section, which seeks to build a definition that better captures the regional aspects in terms of production and industrial employment.

The structure of this article is divided into four more sections besides this introduction. The first section aims, unprecedentedly, to conceptualize de-industrialization at the regional level. Likewise, the following section attempts to enumerate and explain the main causes of de-industrialization at the regional level. In the third section an attempt will be made to apply, in the regions of Brazil, all the conceptual arsenal constructed in the previous sections. Finally, the final considerations.

\section{Regional deindustrialization: a conceptual definition}

The objective of this section will be to discuss the concept of deindustrialization and its ramifications, addressing the various definitions in the literature. In addition, this section explores the various causes that may lead a country or region to a process of de-industrialization. Nevertheless, the regional aspect given both in the definition of concepts and in the causes of deindustrialization constitutes the main contribution of this section.

Several authors point out the importance of industry to economic growth. If we compare with other sectors of the economy, the industry has both backward and forward effects. For Hirschman (1958), the effects of chaining are the overflows through positive externalities to the other sectors that generate greater dynamism in the economy.
Kaldor (1957) also considers industry a differential sector in relation to other sectors of the economy because it has high productivity and greater static economies and dynamics of scale, greater capacity to generate growth and technological progress for all economy and for alleviate external constraints on growth, since industrial products have greater income elasticity of demand. Because of these characteristics, Kaldor (1957) noted that industrialized countries tend to show higher growth than countries that are resource intensive.

In this way, de-industrialization in the negative sense of the term can undermine the dynamism of the economy. However, de-industrialization is not always bad for the economy, actually representing a natural process of economic development. Therefore, it is necessary to define deindustrialization conceptually so that errors of interpretation do not occur when the analysis is performed for the Brazilian economy and regions.

Rowthorn \& Wells (1987) and Rowthorn \& Ramaswany (1999) define deindustrialization as the loss of participation of industrial employment in relation to total employment of the economy on a permanent basis. That is, employment growth tends to be higher in other sectors, especially in the service sector than in the manufacturing industry.

Tregenna (2009) completes redefining this concept, so that deindustrialization is understood as the loss of both employment and value added in their respective totals permanently. This redefinition aimed to incorporate the Kaldorian effects discussed above. In this perspective, according to Oreiro \& Feijó (2010), deindustrialization occurs when the industrial sector loses importance as a source of employment and / or value added for a given economy.

However, the definition of deindustrialization has two ramifications. First, when the loss of participation of the manufacturing industry, whether in terms of employment or value added, occurs concomitantly with a per capita income level of developed country, it is called natural deindustrialization. However, when the turning point starts and the economy has not yet reached a per capita income level of a developed country, it is called early deindustrialization. In the first case, deindustrialization would be a normal result of economic development while in the second case it would reflect a result of economic failure, that is, the economy does not yet have a modern industrial park and runs the risk of having its manufacturing industry deteriorated.

However, these concepts are developed from a national perspective, at the country level without considering the heterogeneity of the process of regional de-industrialization. In other words, the concepts put forward by Rowthorn \& Wells (1987) and Tregenna (2009) can provoke errors of economic policy by 
disregarding this regional aspect. For example, in the face of a diagnosis of early deindustrialization obtained by the classic indicators, the government may decide to adopt a depreciated exchange rate policy to increase the competitiveness of the national industry. As a result, this policy can achieve its objective, but it can also restrict a process of industrialization in a region that was importing capital goods.

Thus, as the objective of this paper is also to carry out an analysis from the regional perspective, it will be necessary to develop some concepts that can correct these possible errors of economic policy.

When it comes to a regional analysis, it is necessary to consider the unequal incidence of the process of deindustrialization at the regional level. That is, a country may be in the process of de-industrialization, but this does not necessarily mean that all regions are in the same situation. That is, it is possible for one region to follow the national trend while another region may be undergoing a process of industrialization. Likewise, it is possible to have an increase in the degree of industrialization of the country with one region accompanying this national trend and another region in the process of deindustrialization. Therefore, the use of the term (de)industrialization (with parentheses) is appropriate because it is possible to have at the same time one region in the process of industrialization and another in the process of deindustrialization.

Therefore, instead of defining only the concept of de-industrialization at the regional level, we will also define two concepts of industrialization that a region can pass: stimulated regional industrialization and / or induced regional industrialization.

The first type of industrialization usually occurs in the early stages of a country's development, when there is an increased demand for manufactured goods that can not be supplied via imports and thus stimulating domestic production. In this case, the region that concentrates the demand-generating activity for industrial goods tends to undergo a process of industrialization faster than the other regions (with an increase of the share of industry in the total production of the country) that do not have the same conditions. Another form that can also occur this kind of industrialization is when the country has difficulties in its trade balance and needs to restrict imports. To this end, it stimulates the production of industrial goods that are substitutes for imports.

"Induced regional industrialization" may be naturally or intentionally induced by an already industrialized or policy-induced region at the state level. The first case tends to occur concomitantly with the deepening of the process of industrialization of a region. In this perspective, the industrialized region demands intermediary goods and inputs from other regions and thus generating a base industry in these latter regions and creating a complementary relationship. This relationship can be induced spontaneously or intentionally by the industrialized region. In the latter case, the region that is industrializing by becoming dependent on credit in the industrialized region.

In the second case, state governments may use various policies to attract industries to their states, such as adequate infrastructure and cheap labor. This case tends to occur when the region is close to full employment, so that the cost of production becomes very high or this industrialized region begins a process of modernization directing some of its activities, especially work-intensive activities, to other regions which present natural conditions more favorable to the production of these goods.

However, the other states to attract these companies are now granting tax exemptions. This is what is conventionally called in the literature for "fiscal war". But with this kind of industrialization, the state stops collecting taxes that turn into profits of established companies, so that by the end of the benefit period, companies tend to move to another state that provides similar benefits.

Note that the regions of a country can go through both types of industrialization in different periods of their economic development. In the initial stage of development there is a process of regional industrialization stimulated that can benefit one region in relation to the others, either by availability of factors of production, infrastructure and market and / or by political factors.

Once the industrialized region is constituted, it can generate spontaneous stimuli so that the other regions can industrialize in the production of inputs that can be used in the industrialized region as it can create these stimuli by providing credit to these regions and, thus, creating a relation of dependency and complementarity between the regions. However, as the technological advance and / or the proximity to full employment in the industrialized region occur, it may find it convenient to shift its labor-intensive industries to other regions, which may be a fiscal war.

Therefore, note that when the national economy has a certain degree of industrialization, the industrialization of one region in some way represents the deindustrialization of another region. For example, in the case of the "fiscal war", deindustrialization occurs in regions that have lost their industries while industrialization has taken place in the other regions that received these industries (When the state-level fiscal war is considered, if this displacement occurs between states in the same region, the result on production and employment of the manufacturing industry in the region will be zero. But if it is between states of distinct regions, we have the process described above).

Thus, it is necessary to define de-industrialization in regional terms. But rather, to simplify the understanding 
we will consider only two regions, one advanced/ industrialized in its industrialization process and another region lagging behind the advanced region. It is also assumed that the backward and advanced regions have, respectively, comparative advantages in the production of capital goods. Also, consider that each region has only one state. Thus, when we were referring to the region, we can also understand how the state. However, this simplification does not change when you are analyzing several regions of a country or several states in a region.

Also consider that the backward region produces capital goods and / or complementary goods to industrial production in the advanced region. The latter, in turn, produces both for the domestic market and for foreign markets. Therefore, it is an open economy. Given these assumptions, a country can present three types of (de) industrialization: the stagnant, the regressive, and the progressive. Each type has a positive and a negative version.

Stagnant regional (de)industrialization occurs when there is a change in the share of industry in each region (or state) in national (or regional) industrial GDP, but so that national (or regional) industry participation in national total GDP (or regional) remains unchanged, as well as the per capita income level of the country. This concept can be broadened in one positive and one negative version.

When the share of industry in the backward region is increasing at the expense of reducing industrial participation in the advanced region, there is a stagnant (de) regional industrialization. That is, when a process of deconcentration of industrial activity occurs. However, this deconcentration can be caused by changes in the productive structure or by the simple displacement of industrial production. The first case may occur when the increased industrial participation of the backward region is achieved through modernization and diversification of its productive structures. In other words, a process of regional import substitution would take place. Thus, to be positive, the productive structure of both regions need not be modified, but the displacement of the production of goods that were produced in the advanced region to the backward region is enough to fit this definition.

However, when the share of industry in the backward regions is reduced to the detriment of increased industrial participation in the advanced region, there is a stagnant regional (de)industrialization. That is, a process of concentration of industrial activity occurs and at the same time the deepening of the comparative advantages of each region. In this case, the differences in the regional productive structure are not only maintained but deepened.

Regressive regional (de)industrialization occurs when there is a change in the share of industry in each region (or state) in the national (or regional) industrial
GDP that results in a decline in national (or regional) industry participation in GDP, but before country to a level of per capita income in a developed country.

Positive regressive regional (de)industrialization may occur when there is an increase in the share of the backward region in the national industrial GDP pari passu with the reduction of the participation of the advanced region, but resulting in a reduction of the participation of the national industry in the GDP, so that this implies a process of deconcentration of industrial production in the country.

However, this deconcentration of industrial activities would be accompanied by the destruction of some activities in the industrialized region and the transfer of other activities of this region to the backward region in order to exploit the advantages that this region presents, such as cheap labor, so that the productive structure becomes more homogeneous. However, the homogeneous denomination here has a negative meaning, since homogeneity occurs through regression of the productive structure of the industrialized region.

Regressive negative regional (de) industrialization occurs when there is a reduction of the participation of the industry of both regions that results in the reduction of the national industrial participation in the GDP accompanied by a regression of the production structure of both regions that causes the concentration of production industry in the advanced region.

Nevertheless, in this case, the productive structure of the backward region is oriented towards the production of goods in which they have comparative advantages while the productive structure of the developed region is regressed towards the production of goods of low added value, but with an even higher added value to the backward region.

On the other hand, progressive regional (de) industrialization occurs when there is a change in the share of industry in each region (or state) that implies a reduction in the share of national (or regional) industry in GDP, but in such a way that the country has reached a per capita income level of a developed country.

In other words, it is a process of (de) industrialization in which the national economy as a whole is growing, therefore, desirable for the country. However, when this economic growth implies the deconcentration of industrial production in the region, there is a process of progressive (de) industrialization. Otherwise, if it results in the concentration of industrial production in the advanced region, there is a progressive (de) industrialization process negative.

Thus, in the case of positive progressive regional (de) industrialization, the productive structure of the backward region is oriented towards the production of goods with higher added value resulting from a process of deconcentration of industrial activities 
provided by the modernization of the productive structure of the advanced region. Therefore, there would be a deconcentration of industrial production resulting from the modernization of activities in the industrialized region that makes the productive structure of the country more modern and somewhat more homogeneous.

In this concept of (de) industrialization there are still three observations. First, the modernization of the productive structure is what causes the reduction of the participation of the value added of the industrialized region through increased productivity. Therefore, the reduction of national industry's share of GDP is explained by the increase in productivity, which leads to both a reduction in employment share and value added. Second, homogeneity has a positive meaning, as the backward region moves to a more advanced technological stage (though still lagging behind the so-called advanced region) and / or the advanced region is benefited by technological advancement.

Finally, the concept of regressive deindustrialization has some correspondence with the concept of early deindustrialization, while the concept of progressive deindustrialization has similarities with the concept of natural deindustrialization, previously seen at the country level. Defining the concepts of regional deindustrialization, what are the main factors that can lead a region and, consequently, a country to a deindustrialization process? The answer to this question can be found in the next section.

\section{The main causes of regional deindustrialization}

Known the concepts related to regional deindustrialization, this section aims to explain the main causes that can trigger a deindustrialization process in regional terms.

Regional de-industrialization may be caused by internal factors such as: (i) increasing per capita income, (ii) technological advancement, (iii) national/regional development policy, (iv) cumulative taxation, (v) "war Supervisor".

Regional deindustrialization can occur when the advanced or industrialized region reaches a high level of per capita income and a situation close to full employment. In this case, there is a transfer of workforce to the service sector, making the cost of production higher in the manufacturing industry. Indeed, industries tend to move to other backward regions which have a lower labor cost. Thus, generating a process of deindustrialization in the developed region and industrialization in the backward region.

When the industrialized region has a technological breakthrough, it needs to dispose of its obsolete machines and equipment. One way to do this is to transfer all or part of this productive structure to the backward regions. In this case, there is a process of deindustrialization in the first region caused by the increase in productivity provided by the technological advance and at the same time a process of industrialization in the backward regions caused by the transfer of the obsolete productive structure.

In the case of a national/regional development policy in order to stimulate industrialization (whether of autonomous production or of complementarity), the backward region starts to obtain a growth of industrial production superior to that of the advanced region, so that its industrialization can mean the deindustrialization of the industrialized region. That is, when deindustrialization is treated in regional terms, it can occur when regions that do not yet own an industrial park begin their industrialization process, increasing their share of GDP in relation to the already industrialized region (Cano, 2014).

The form of taxation can also lead to the de-industrialization of a region. When the tax is collected on the sale of the good during its entire production cycle, the same company starts to produce part of the inputs that it uses, thereby avoiding cumulative taxation. That is, there is a tendency for vertical integration of production by the company. Thus, the advanced region begins to produce part of its inputs that it previously acquired from the backward region, so that there is a deindustrialization process in the latter region.

Still within the tax questions, the deindustrialization can be brought about by denominated "fiscal war". In the absence of a national / regional development policy, states can provide tax exemptions for industries to settle in their territories. When these industries are attracted to other states that have refused to grant the same tax incentives, deindustrialization tends to be only regional once the industry moves from one region to another. However, when the industry intends to open a new company, ceteris paribus, the state that provides greater tax incentives tends to increase its share in GDP while other states tend to have their shareholdings reduced (Cardozo, 2010).

Deindustrialization can also be caused by external factors such as: i) global value chains; (ii) the Dutch disease, (iii) the intensification of international competition.

In the last 25 years there have been major changes in international trade that have modified the modus operandi of large corporations. The production process of the company began to be distributed throughout the world, occurring a de-verticalization from the design of the products until its commercialization, which contributed to the formation of global value chains. This new form of organization affects countries and especially regions that are not part of the production chain, in other words, this new organizational form can provoke a process of industrialization in the 
regions that are part of the chain and a process of de-industrialization in the regions that are outside (Sampaio, 2015).

Thus, regional deindustrialization may be the result of this new organizational form of international manufacturing production that takes place through global value chains. In this case, since the objective of foreign direct investment (FDI) is to appropriate part of the domestic market, much of this investment is directed towards the final phase of the production process, in which the companies are only maquiladoras, that is, imported (According to Sampaio (2015), this process is different from import substitution, since the decision to aggregate value of goods produced in the country is determined by international companies. In other words, it is a "subordinate" insertion into the global value chains). As a result, the advanced state of being the main receiver of the IDE ends up breaking production relations with the backward states, so that these states now have a process of deindustrialization that is not only relative but also absolute.

In general, the new organizational form of international manufacturing production tends to reduce the dynamics of interstate / regional trade by reducing the multiplier effect of industrial production in the country, so that this process modifies interstate commerce, aggravates the fiscal war and undermines integration regional manufacturing industry in the country.

The "Dutch disease" (derived from the discovery of natural resources, the appreciation of commodity prices or greater financial openness), which is manifested by a real overvaluation of the exchange rate, is also another factor that can provoke a process of regional deindustrialization. This exchange overvaluation by reducing the competitiveness of the advanced region industry, both domestically and abroad, leads to a reduction in industrial production. Since the production of the backward region is complementary to the production of the industrialized region, the industrial production of the backward region is simultaneously reduced. That is, both regions undergo a process of de-industrialization. However, if exchange overvaluation also induces the replacement of intermediate goods by similar imported ones, deindustrialization tends to be faster in the backward region than in the advanced region (Silva \& Lourenço, 2014b).

An increase in international competition can also lead to a de-industrialization process in both regions. In this case, in the absence of protectionist policies in favor of the domestic industry, a strong competitor can generate the substitution of the consumption of domestic goods for imported goods and, therefore, cause the reduction of domestic industrial production in the advanced region and, consequently, the backward region.
These two factors may potentialize the deindustrialization process in the advanced region. The demand of this region is made up of the consumption of industrial goods carried out within it, the consumption of the backward region and the exhortations. First, the exchange overvaluation and the increase of foreign competition causes the substitution of domestic consumption for imported goods and at the same time reduces exports, which can lead to a process of de-industrialization in the advanced region.

But the backward region tends to have a complementary relationship with the industrialized region, ie the backward region produces intermediate goods to be used in the processing industry of the advanced region. The decline in demand for industrial goods in the advanced region reduces the demand for intermediate goods in the backward region, which in turn leads to lower income levels and thus further reduces demand for industrial goods in the industrialized region, kind of vicious circle in the regional and national economy. This vicious circle can be aggravated if advanced-state firms seek to have productive structures based on global value chains, so that they begin to seek the substitution of domestic inputs for imports. In addition, the vicious circle can be intensified in the face of an internal and / or external recession, leading to a reduction in consumption and / or exports.

Indeed, as the advanced region is also responsible for the production of capital goods, a drop in the demand for consumer goods and intermediaries tends to affect the industrialized region more seriously than the backward region.

In addition to the factors explained above, an issue that can not be ignored in relation to the causes of deindustrialization refers to the negative externalities generated by industrial activity, such as pollution. An industrialized region tends to have high levels of pollution, which can generate social pressure to reduce these rates. If industry can not find a way to adapt to new environmental requirements without the need to reduce its output, industry can move to another region where the benefit of job and income generation is greater than the population derived from increased pollution (See Cano, 2011).

Defining the concepts of regional deindustrialization and its causes, the next section seeks to analyze the case of the Brazilian economy in regional terms.

\section{4 (Des)industrialization regional in Brazil}

Despite the significant advances that took place within the debate on Brazilian deindustrialization, this did not advance in the regional discussion. On the contrary, it has treated deindustrialization in a 
homogeneous way between the regions, disregarding the concentration of productive activities in the regions of the country. This paper seeks to advance this gap, with the aim of drawing attention to the regional differences in the deindustrialization process.

In this sense, in order to verify empirically the type of deindustrialization in each region according to the concepts developed in section 1 , the method is summarized to a descriptive analysis of production and industrial employment data in the regions of Brazil, considering the total of each region in relation to employment and national industrial production and in relation to GDP and total employment in the country.

In Brazil there are five regions: North, Northeast, Southeast, South and Center-West. Of these regions, the Southeast region for having more technologically developed industries is considered the most developed while the other four regions are considered backward for inverse reasons.

At the beginning of the 20th century, Brazil was an agro-exporting country whose main product was coffee. Coffee production was concentrated in the Southeast region, so that economic policy was focused on this region. With the difficulties of the crisis of 1929 and the coffee crisis, coffee growers noted that it made no sense to continue investing in coffee production, so it was necessary to find another activity that could invest their resources. On the other hand, it was in the interest of the government to develop the manufacturing industry more intensively, as industrial goods put pressure on trade balance deficits.

In effect, the government started to grant incentives for the development of an industrial sector that would allow to substitute part of the imports. Faced with this, industry has quickly become the destination of the investments of former coffee growers and foreign capital. Thus began the process of industrialization by substitution of imports (Tavares, 1972). Thus, the other regions were inserted in this process only in a dependent and complementary way, supplying raw material for the Southeast region (Araujo, 2000).
The disclosure of the Brazilian National Accounts in the 1950s revealed that the Southeast concentrated almost $80 \%$ of all industrial production in the country. With the indignation of several layers of society in other regions demanding priority treatment in the sense of implementing regional development policies. In this context, several regional superintendencies (SUDENE, SUDESUL, SUDECO and SUDAM) were created with the purpose of developing their regions and thus alleviating the delay in relation to the developed region, the Southeast (Silva \& Teixeira, 2014).

However, these regional policies had little effect, as industrial production remained concentrated in the Southeast region. With the end of developmental policies and the beginning of neoliberal policies in the decade of 1980-90, the gap between the Southeast and the other regions increased. In effect, the states started to grant fiscal incentives to attract companies, so that regional heterogeneity was aggravated.

In the last decade, the 2000s, there has been a return to regional policy and planning. The backward regions had higher growth than the Southeast region, which contributed to a slight process of deconcentration of income and production in the Brazilian economy.

As can be seen in Figure 1, GDP share of the advanced region, Southeast, in the country's GDP fell from $64.2 \%$ in 1995 to $53.2 \%$ in 2015 . While the share of GDP in the South region lost $1.0 \mathrm{pp}$, the indicator of the other regions increased in the same period. Therefore, it can not be denied that there was a process of deconcentration of production / national income in the period in focus.

Concomitant with this regional income deconcentration process, there is a deconcentration of the production of the transformation industry in regional terms. Thus, it can be seen from Table 1 that the share of the industry in relation to the value added of the Southeast region in national GDP fell from $63.7 \%$ in 1995 to $55.5 \%$ in 2015 , a decrease of $8.2 \mathrm{pp}$ in the period. In terms of employment, the Southeast

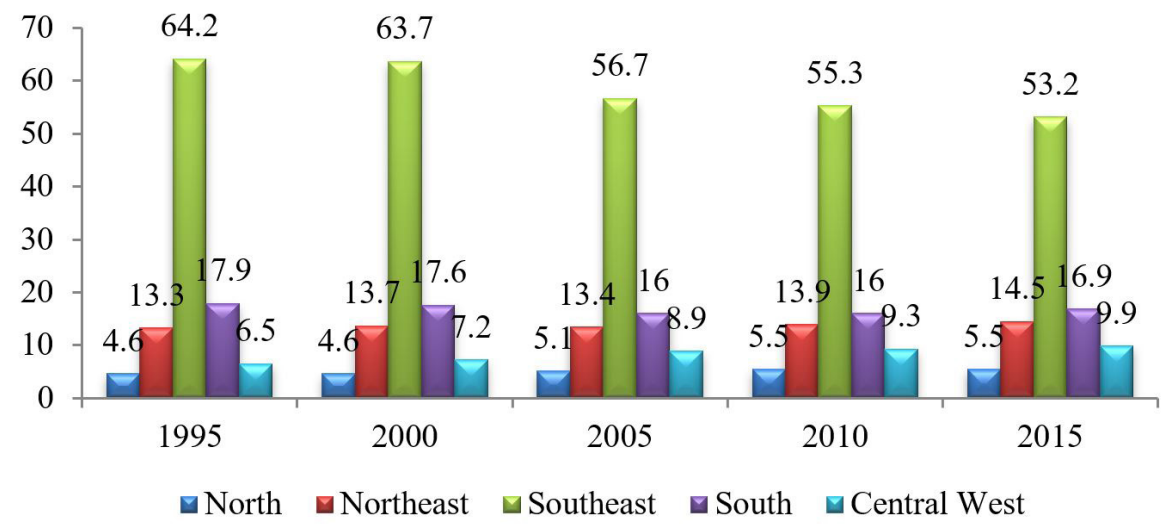

Figure 1. Share of regional GDP in GDP Brazil: 1995-2015. Source: Regional Accounts, IBGE (2018). 
Table 1. Participation of the Regional Transformation Industry in the National Transformation Industry: 1995-2015.

\begin{tabular}{|c|c|c|c|c|c|c|c|c|c|c|}
\hline \multirow{2}{*}{ Region } & \multicolumn{5}{|c|}{ Added value (\%) } & \multicolumn{5}{|c|}{ Employment (\%) } \\
\hline & 1995 & 2000 & 2005 & 2010 & 2015 & 1995 & 2000 & 2005 & 2010 & 2015 \\
\hline Southeast & 63.7 & 61.5 & 61.9 & 60.2 & 55.5 & 61.1 & 55.5 & 52.9 & 52.5 & 50.6 \\
\hline South & 21.1 & 21.7 & 20.6 & 21.1 & 23.4 & 22.7 & 25.4 & 26.0 & 25.4 & 26.2 \\
\hline North & 4.4 & 4.4 & 4.7 & 4.7 & 4.6 & 2.5 & 3.0 & 3.8 & 3.5 & 3.5 \\
\hline Central West & 2.1 & 2.5 & 4.1 & 5.1 & 5.8 & 2.8 & 4.1 & 4.6 & 5.3 & 6.2 \\
\hline Northeast & 8.8 & 9.9 & 8.7 & 9.0 & 10.7 & 10.8 & 12.0 & 12.7 & 13.3 & 13.6 \\
\hline Brazil & 100 & 100 & 100 & 100 & 100 & 100 & 100 & 100 & 100 & 100 \\
\hline
\end{tabular}

Source: Regional Accounts, IBGE (2018).

increased from a participation of $61.1 \%$ in 1995 to $50.6 \%$ in 2015.

In relation to the states (See Silva (2017) for an analysis of the states of the Southeast region), Rio de Janeiro had a share gain between 1995 and 2002, but lost $2.5 \mathrm{pp}$ in relation to 2015. In the state of São Paulo, the decline was still higher, $7.6 \mathrm{pp}$ between 1995 and 2015. The same tendency in relation to employment, Rio de Janeiro had a loss of $2.3 \mathrm{pp}$ and the state of São Paulo had a loss of 9.4 pp between 1995 and 2015.

The participation of the North region (value added) increased from $4.4 \%$ to $4.6 \%$, as well as the participation of the Northeast region, which increased from $8.8 \%$ in 1995 to $10.7 \%$ in 2015 . In relation to employment, there was also a gain in participation.

The North region increased from $2.5 \%$ in 1995 to $3.5 \%$ in 2015 . The Northeast rose from $10.8 \%$ to $1.6 \%$ in the same period. But in relation to the states, both regions continue to have small shareholdings relative to the states of the Southeast and South, either in terms of added value or employment.

The North region increased from $2.5 \%$ in 1995 to $3.5 \%$ in 2015 . The Northeast went from $10.8 \%$ to $13.6 \%$ in the same period. But in relation to the states, both regions continue to have small shareholdings in comparison to the states of the Southeast and South, either in terms of added value or employment.

The participation of the Central-West region also showed a significant increase, from $2.1 \%$ to $5.8 \%$ in relation to the value added in the period 1995 to 2015. For the share of employment, the increase was even more significant, from $2,8 \%$ to $6.2 \%$ in the same period. Nevertheless, this region still continues with a little relevant industry in the national GDP.

Thus, the South region had an increase in the participation of the manufacturing industry in the GDP, from $21.1 \%$ to $23.4 \%$, that is, an increase of more than two percentage points. In employment, the increase was higher, from $22.7 \%$ in 1995 to $26.2 \%$ in 2015. However, this participation gain is due to the performance of the industry of the state of Santa
Catarina and of Paraná, but not of Rio Grande of North (Bender, 2016).

In general, a process of deconcentration of the industrial production in Brazil is observed, since the developed region lost relevance in the national industry, although it continues being extremely important in the productive chain of the country.

But has this process of deconcentration of the national industry been followed by the increase in the participation of the manufacturing industry in the country's GDP? In other words, (de) industrialization in Brazil is stagnant, progressive or regressive?

When analyzing the data of the transformation industry for Brazil as a whole, in terms of value added, there is a significant drop in its share of the total added value of the Brazilian economy. As can be seen in Figure 2, the participation of the sector in focus fell to levels close to the pre-industrialization period, with a U-trajectory reversed throughout the analyzed period (See Silva, 2014).

The manufacturing industry followed a growth trend until 1986, when the turning point occurred. In that year the share of the processing industry was almost 35\%. In 2015 this indicator was 12\%. On the other hand, the service sector showed a significant increase in participation, reaching $70 \%$ in 2015 , which characterizes a deindustrialization process. Given these circumstances, the country's productive structure has been focused on labor-intensive activities and natural resources.

However, it is necessary to identify whether this process was due to a phase of economic development or if it was a harmful anomaly to the Brazilian industry. In other words, it is necessary to identify the level of per capita income at the time the turning point occurred. Many studies (Oreiro \& Feijó, 2010; Silva \& Lourenço, 2014a) show that per capita income in 1986 was US $\$ 4,753$, lower income than developed countries (about US $\$ 15,000$ ) when they reached the turning point. Thus, there are unmistakable signs of a process of early de-industrialization in the Brazilian economy.

When analyzing the process of deindustrialization in terms of employment, Figure 3, there is a tendency 


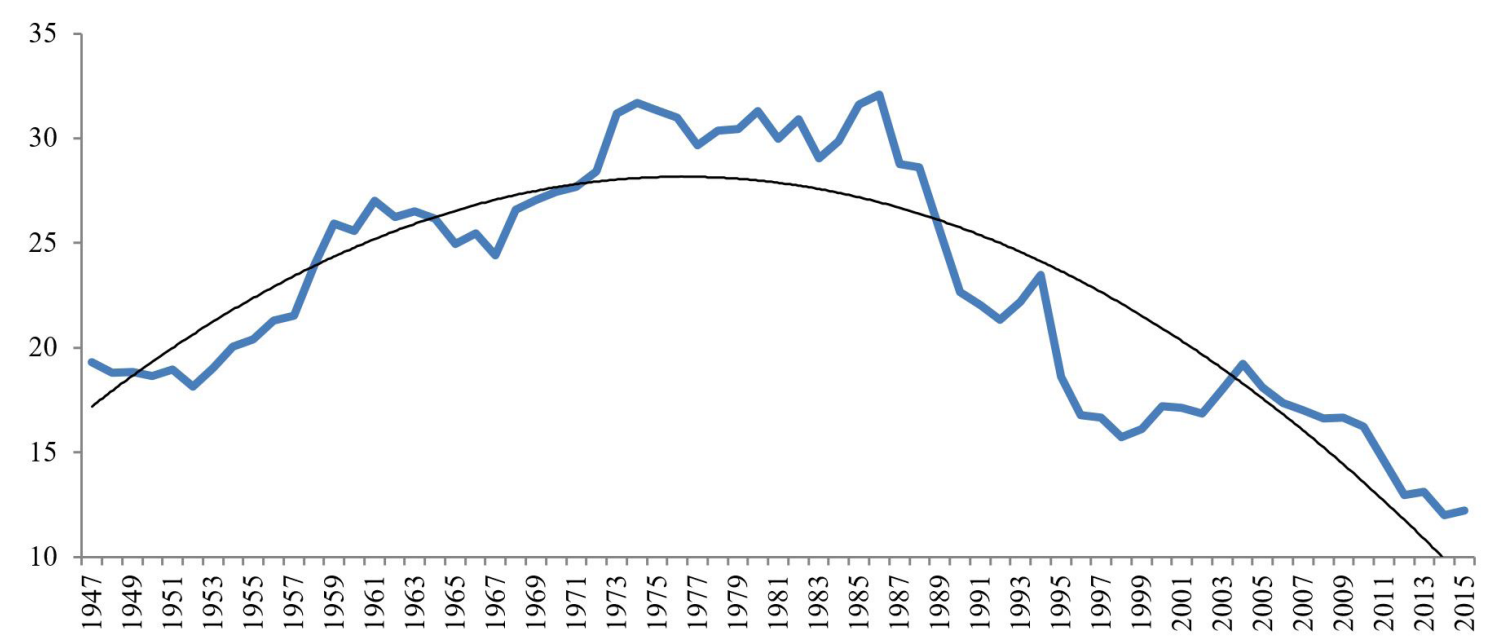

Figure 2. Participation of the Manufacturing Industry in GDP, Brazil: 1947-2015.Source: IBGE (2018).

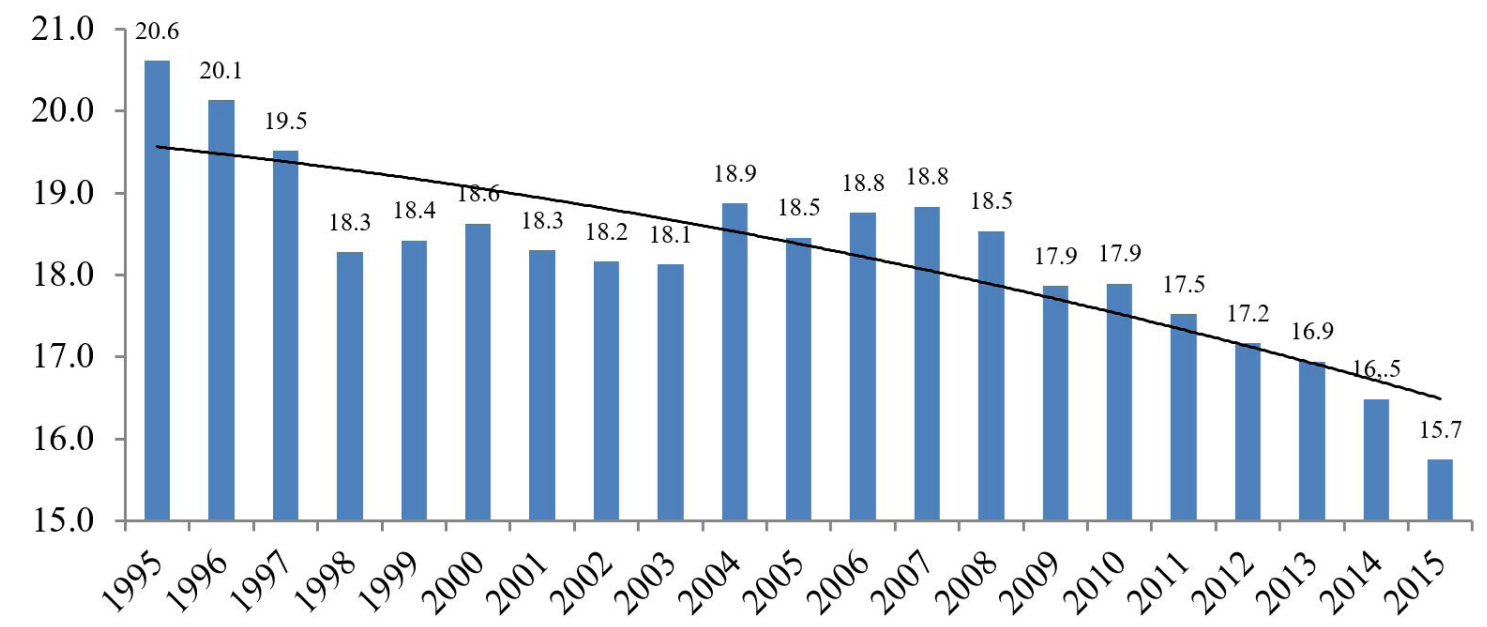

Figure 3. Employment Share of the Manufacturing Industry in Total Employment, Brazil: 1995-2015. Source: IBGE (2018).

of loss of participation of the employment of the transformation industry in the total employment in the period of 1995 to 2015 . Being that this loss occurred more consistently from 2007 In 1995 the processing industry held $20.6 \%$ of total employment, this percentage fell to $18.8 \%$ in 2007 and fell to $15.7 \%$ in 2015 , a smaller share of the data series under analysis.

This loss of participation can be explained by the faster growth of the other sectors in relation to the manufacturing industry, especially the services and commerce sector. However, between 2014 and 2015 there was a loss of employment, not only relative, but also absolute, as there was a reduction of more than 600 thousand jobs in the industry. Outsourcing and modernization in the manufacturing industry were other factors that contributed to the lack of industrial employment dynamics in the last twenty years.
Thus, a regressive and positive deindustrialization process is observed, either in terms of added value or employment, since the process of deconcentration of production and industrial employment was followed by a loss of participation in GDP and in national employment, where the less developed regions showed an increase in shareholdings to the detriment of the advanced region.

However, this paper does not seek to discuss whether or not the Brazilian economy is going through a process of deindustrialization, but to analyze this loss of participation of value added and employment of Brazilian industry in regional terms. In other words, it aims to verify if the occurrence of deindustrialization at the regional level presents itself homogeneously and show the contribution of each region in this process. 
Table 2 presents the participation of the regional transformation industry in the GDP of Brazil, so that it is possible to identify the contribution of each region in the deindustrialization process of the country.

For example, in 1995 the share of the manufacturing industry in the national GDP was $24.5 \%$; of this percentage, the Southeast region accounts for $15.6 \%$ of GDP. The same can be observed for employment.

Thus, the data in Table 2 show that the manufacturing industry lost share in terms of added value and employment. In the first case, it went from $24.5 \%$ in 1995 to $12.2 \%$ in 2015 , and in relation to employment the decrease was from $20.6 \%$ to $15.7 \%$ in the same period.

As can be seen, the process of deindustrialization in Brazil does not present itself homogeneously among the Brazilian regions and states, occurring more intensely in some localities than in others. The Southeast region, for example, had a loss of 8.8 percentage points, from $15.6 \%$ in 1995 to $6.8 \%$ in 2015 . In the same sense, the South region had a loss of $2.3 \mathrm{pp}$ while the Northeast lost $0.8 \mathrm{pp}$, the North lost $0.5 \mathrm{pp}$ On the other hand, the Central-West region obtained a gain of 0.2 pp between 1995 and 2015. That is, of the $12.3 \%$ loss that the industry had in the period, the Southeast region was responsible for $8.8 \mathrm{pp}$, which shows a serious process of de-industrialization in this region (See Silva (2017), Pereira \& Cairo (2018) for an analysis of the states of the Southeast region).

In relation to the states, the largest contribution to the process of national deindustrialization was presented by the state of São Paulo with 6.5 pp between 1995 and 2015. In the South, deindustrialization is more serious in the state of Rio Grande do Sul, with a contribution of $1.4 \mathrm{pp}$, in the Northeast the state of Bahia contributed with $0.3 \mathrm{pp}$, and in the North the state of Amazonas contributed with $0.4 \mathrm{pp}$. However, in the Center-West region, most states contributed to increase the share of industry in GDP, but insignificantly in the face of the loss presented by other Brazilian states (See Botelho et al. (2016) for a state analysis of the deindustrialization process). The same trend is observed in terms of employment, but to a lesser extent.
In this way, the Brazilian economy suffers from a regressive and positive deindustrialization process, which occurs more or less intensively from region to region. But what are the factors that can explain this national and at the same time regional deindustrialization in the Brazilian economy?

Several factors have contributed to the reduction of regional disparities in income and in the manufacturing industry. These include improvements in income derived from income redistribution policies, the valuation of the minimum wage, increase in formal employment, expansion of credit, increase in public investment and growth and diversification of exports (Silva \& Teixeira, 2014). These factors, by provoking an increase in income in the backward regions, generated an increase in the demand for industrial goods and thus increased private investment in the industry and consequently its share in relation to the advanced region. However, as it deals with the consumption of mass goods, some labor-intensive industries started to move from the Southeast to the other regions.

The continuation of the fiscal war in the period under review contributed in some way to the deindustrialization of the Southeast since the less developed regions continued with the policy of incentives for industrial enterprises to settle in their territories. The fiscal war has left an absolute de-industrialization in regions that have lost their factories and at the same time may have led the more productive workers, generating a process of income migration.

Another explanation for the evolution of the manufacturing industry in the backward regions can be found in the exchange rate, since the period under analysis is characterized by an exchange overvaluation. Between 1995 and 2015 the exchange rate has an average trajectory of strong exchange appreciation, being an instrument of inflation control. First as a currency anchor for the Real Plan and then in the Inflation Target System. On the other hand, the competitiveness of industrial goods reduced significantly, which led to a fall in exports and consequently the deterioration of the trade balance of the manufacturing industry in the period in focus.

Table 2. Participation of V.A. of the Regional Transformation Industry in National GDP: 1995-2015.

\begin{tabular}{|c|c|c|c|c|c|c|c|c|c|c|}
\hline \multicolumn{6}{|c|}{ Region Added value (\%) } & \multicolumn{5}{|c|}{ Emprego (\%) } \\
\hline & 1995 & 2000 & 2005 & 2010 & 2015 & 1995 & 2000 & 2005 & 2010 & 2015 \\
\hline Southeast & 15.6 & 15.5 & 10.8 & 9.0 & 6.8 & 12.6 & 10.3 & 9.8 & 9.4 & 8.0 \\
\hline South & 5.2 & 5.5 & 3.6 & 3.2 & 2.9 & 4.7 & 4.7 & 4.8 & 4.6 & 4.1 \\
\hline North & 1.1 & 1.1 & 0.8 & 0.7 & 0.6 & 0.5 & 0.6 & 0.7 & 0.6 & 0.6 \\
\hline Central West & 0.5 & 0.6 & 0.7 & 0.8 & 0.7 & 0.6 & 0.8 & 0.9 & 0.9 & 1.0 \\
\hline Northeast & 2.1 & 2.5 & 1.5 & 1.3 & 1.3 & 2.2 & 2.2 & 2.3 & 2.4 & 2.1 \\
\hline Brazil & 24.5 & 25.2 & 17.4 & 15.0 & 12.2 & 20.6 & 18.6 & 18.5 & 17.9 & 15.7 \\
\hline
\end{tabular}

Source: Regional Accounts, IBGE (2018). 
As the Southeast region is the most industrialized and the one that produces goods for both the domestic market and the foreign market, the negative effect of exchange overvaluation tends to affect this region more aggressively than the others. Coupled with this exchange overvaluation, Chinese products have become highly competitive reducing the domestic and foreign market for industrial goods produced, especially in the Southeast. Since this region is demanding of inputs from other regions, the exchange overvaluation ended up generating indirect negative effects on the other regions of the country.

The worsening crisis in post-2010 Europe has also contributed to reducing the competitiveness of Brazilian products. Faced with a slowdown in demand, there was an excess supply that caused the fall in international prices of industrial goods, and industrial goods were tradeable, a disincentive to their production.

Besides these factors, the loss of competitiveness of the Brazilian industry is also due to the low labor productivity in the sector. According to data from the National Confederation of Industry (CNI), between 1995 and 2003 the average rate was negative and after growing at an average rate of $1.0 \%$ between 2004 and 2010, the average rate of productivity was not negative again growth of $2.6 \%$ in 2013. In regional terms, average productivity growth remained stable. Therefore, the analysis of the data shows a trend of deindustrialization in Brazil of the regional regressive positive type.

\section{Conclusion}

In recent years the motives of deindustrialization have provoked various academic debates. In the developing countries this debate has generated different opinions in the scope of its occurrence, intensity and precocity. Where precocity has been targeted higher due to "natural resource harm" or "Dutch disease".

Current studies regarding Brazilian deindustrialization show divergent positions regarding their intensity and occurrence, observing that, for the most part, divergences in positions are based on different theoretical-conceptual frameworks. This paper aims to contribute to the debate on Brazilian deindustrialization by analyzing its presentation at the regional level.

In the first section a brief review of the literature on the concepts of deindustrialization and its ramifications was carried out, as well as new development for the regional perspective. In the following section, we attempted to enumerate the main causes that can lead a region to a deindustrialization process.

In the third section an analysis of deindustrialization in the Brazilian economy was carried out. Initially the data were shown at national level and it was observed that the country suffers from a regressive but positive deindustrialization process. Sub-industrialization was then analyzed at the regional level and it was found that in the Southeast region there is a greater loss of participation in value added and in the employment of the manufacturing industry, that is, where the deindustrialization process presents itself with greater gravity.

At the end of the study, it was verified that the deindustrialization in the country is of the regressive and positive type, since the loss of participation of the processing industry of the Southeast region occurred at the same time as gains of participation in other regions, deconcentrating the production industry in the country.

However, this work only initiates the discussion, and new developments are necessary to corroborate or not with the results found in this research. Therefore, there are several fields that can still be explored, for example, to carry out a research that seeks to capture if the deconcentration process in force in the country is about deconcentration of activities or production.

\section{References}

Araujo, T. B. (2000). Ensaios sobre o desenvolvimento brasileiro: heranças e urgências. Rio de Janeiro: REVAN.

Barros, O., \& Pereira, R. R. (2008). Desmistificando a tese de desindustrialização: reestruturação da indústria brasileira em uma época de transformações globais. In O. Barros \& F. Giambiagi (Org.). Brasil globalizado: o Brasil em um mundo surpreendente (pp. 299-330). Rio de Janeiro: Elsevier.

Bender, R., Fo. (2016). Dinâmica industrial: evidencias para o Brasil e para as regiões Sudeste e Sul. Ensaios FEE, 37(3), 739-768.

Bonelli, R., \& Pessôa, S. A. (2010). Desindustrialização no Brasil: um resumo da evidência (Texto para Discussão, no. 7). São Paulo: FGV/IBRE.

Bonelli, R., \& Pinheiro, A. C. (2012). Competividade e desempenho industrial: mais que só câmbio. In Anais do XXIV Fórum Nacional. Rio de Janeiro: INAE.

Botelho, M. R., Sousa, G. F., \& Avellar, A. P. M. (2016). A incidência desigual do processo de desindustrialização nos estados brasileiros. Revista de Economia, 43(3), 1-22.

Bresser-Pereira, L. C., \& Marconi, N. (2008). Existe doença holandesa no Brasil? In Anais do IV Fórum de Economia de São Paulo. São Paulo: Fundação Getúlio Vargas.

Cano, W. (2011). Industrialização, desindustrialização e políticas de desenvolvimento. Revista FAAC, 1(2), 155-164.

Cano, W. (2014). (Des)industrialização e (sub)desenvolvimento. Cadernos do Desenvolvimento, 9(15), 139-174.

Cardozo, S. A. (2010). Guerra Fiscal no Brasil e alterações das estruturas produtivas estaduais desde os anos 1990. (Tese de doutorado). Instituto de Economia, Universidade Estadual de Campinas, Campinas.

Hirschman, A. O. (1958). The strategy of economic development. New Haven: Yale University Press. 
Instituto Brasileiro de Geografia e Estatística - IBGE. (2018). Contas nacionais e regionais. Retrieved in 2018, January 21, from http://www.ibge.gov.br

Kaldor, N. (1957). A model of economic growth. Economic Journal (London), 67(268), 591-624. http://dx.doi. org/10.2307/2227704.

Oreiro, J. L., \& Feijó, C. A. (2010). Desindustrialização: conceituação, causas, efeitos e o caso brasileiro. Revista de Economia Política, 30(2), 219-232. http://dx.doi. org/10.1590/S0101-31572010000200003.

Pereira, W. M., \& Cairo, S. A. F. (2018). Desindustrialização e mudança estrutural na região sudeste: um estudo comparado. Revista Brasileira de Estudos Regionais e Urbanos, 12(2), 173-204.

Rowthorn, R., \& Ramaswany, R. (1999). Growth, trade and de-industrialization. IMF Staff Papers, 46(1), 1-20.

Rowthorn, R., \& Wells, J. (1987). De-industrialisation and foreign trade. Cambridge: Cambridge University Press.

Sampaio, D. P. (2015). Desindustrialização e estruturas produtivas regionais no Brasil (Tese de doutorado). Instituto de Economia, Universidade Estadual de Campinas, Campinas.

Silva, J. A. (2014). Desindustrialização e doença holandesa: o caso brasileiro. Indicadores Econômicos FEE, Porto Alegre, 41(3), 67-82.
Silva, J. A., \& Lourenço, A. L. C. (2014a). Desindustrialização em debate: teses e equívocos no caso da economia brasileira. Indicadores Econômicos FEE, 42(2), 57-76.

Silva, J. A., \& Lourenço, A. L. C. (2014b). Revisitando o conceito de desindustrialização. Revista OIKOS, 13(1), 57-73.

Silva, J. A., \& Teixeira, M. S. G. (2014). Desconcentração no Brasil: Nordeste, da Sudene aos anos 2000. Revista Economica do Nordeste, 45(3), 118-134.

Silva, J. S. (2017). A desindustrialização na região Sudeste Acta Scientiarum. Human and Social Sciences, 39(3), 305-315.

Spíndola, F. D., \& Lima, J. P. (2015). Desindustrialização regional no Brasil. Nova Economia, 27(2), 247-293.

Tavares, M. C. (1972). Auge e declínio do processo de substituição de importações no Brasil. In: Tavares, M. C. Da substituição de importações ao capitalismo financeiro: ensaios sobre a economia brasileira. Rio de Janeiro: Zahar.

Tregenna, F. (2009). Characterizing deindustrialization: an analysis of changes in manufacturing employment and output internationally. Cambridge Journal of Economics, 33(3), 433-466. http://dx.doi.org/10.1093/ cje/ben032. 